\title{
Nutritional ecology of the giant clams Tridacna tevoroa and T. derasa from Tonga: influence of light on filter-feeding and photosynthesis
}

\author{
D. W. Klumpp ${ }^{1}$, J. S. Lucas ${ }^{2}$ \\ ${ }^{1}$ Australian Institute of Marine Science, PMB 3, Townsville MC, Queensland 4810, Australia \\ ${ }^{2}$ Zoology Department, James Cook University, Townsville, Queensland 4811, Australia
}

\begin{abstract}
This study compares the nutrition of 2 species of giant clam (Tridacnidae) from Tonga: the rare Tridacna tevoroa, which inhabits relatively deep waters $(9$ to $33 \mathrm{~m})$, and $T$. derasa, a more common and widespread species usually found in shallower habitats ( 1 to $20 \mathrm{~m}$ ). The principal aim of the comparison was to determine how $T$. tevoroa survives at greater depths than other tridacnid species. Rates of filter-feeding, respiration and the photosynthesis-irradiance response were measured in clams of a wide size range (ca $20 \mathrm{~mm}$ to ca $500 \mathrm{~mm}$ ) which had been acclimated to 4 levels of shading, simulating depths of 1, 5, 15 and $28 \mathrm{~m}$. Carbon utilisation by the tissues of the host, partitioned into growth and respiration components, were compared with the supply of carbon via filter-feeding and photosynthate from zooxanthellae. Rates of respiration, growth, filter-feeding and maximum photosynthesis did not vary between species or level of shading. Only $r$ tevoroa significantly increased its photosynthetic efficiency with increasing depth. Consequently, it was able to rely on phototrophy while at greater depth (ca $10 \mathrm{~m}$ deeper) than $T$. derasa. At their normal depths, phototrophy provides most ( $T$. tevoroa: $70 \%$ at $28 \mathrm{~m}, 105 \%$ at $15 \mathrm{~m}$ ), if not all ( $\mathrm{T}$. derasa), of the carbon required for growth plus maintenance, and filter-feeding is a relatively minor source $(8$ to $14 \%$ ). These 2 species contrast with the largest tridacnid species, T. gigas, in which filter-feeding is a major source of carbon, at least in small clams, and the relative allocation of carbon for growth compared to respiration is much higher.
\end{abstract}

KEY WORDS: Giant clam - Tridacna derasa - Tridacna tevoroa Filter-feeding · Coral reef - Respiration . Photosynthesis - Photoadaptation - Carbon budget

\section{INTRODUCTION}

Rosewater (1965) effectively commenced the modern era of research on giant clams (Family Tridacnidae) by providing the first comprehensive study of their taxonomy. He recognised 6 extant species in 2 genera. Subsequently, 3 less-common species have been described: Hippopus porcellanus Rosewater, Tridacna tevoroa ${ }^{1}$ Lucas et al., and $T$. rosewateri Sirenko and Scarlato. T. tevoroa occurs in the eastern Lau Islands of Fiji and in Tonga (Lucas et al. 1991, Ledua et al. 1993), and is notable for occurring at greater depths than other tridacnid species. Ledua et al. (1993) tabulated recent collections of $T$. tevoroa, with mean depths and ranges being $27 \mathrm{~m}$ and 20 to $33 \mathrm{~m}$ for specimens from

\footnotetext{
${ }^{1}$ Recently identified as Tridacna mbalavuana Ladd (unpubl.)
}

Fiji and $26 \mathrm{~m}$ and 9 to $33 \mathrm{~m}$ for specimens from Tonga. Giant clams obtain their nutrition mainly from translocated photosynthates from symbiotic zooxanthellae in their exposed mantle tissues (see recent reviews by Fitt 1993, Lucas in press). They are thus limited to relatively shallow areas by light attenuation and most occur at less than $10 \mathrm{~m}$ depth. Where they occur at greater depths, it is usually in very clear oceanic water. Thus, large Tridacna derasa (Röding) were commonly found at 10 to $20 \mathrm{~m}$ depth in the clear oceanic conditions of the windward islands and barrier reefs of eastern Fiji (Adams et al. 1988). In these regions, juveniles of $T$. derasa were usually found attached to the tops and sides of coral outcrops at shallow depths, from which they detached and fell when their byssus broke (Adams et al. 1988). T. derasa and T. tevoroa co-occur in oceanic barrier reef and island conditions of Fiji and 
Tonga, but $T$. tevoroa occurrence extends to a greater depth and, judging from its size distribution, it recruits at these depths.

Giant clams also filter-feed, like most bivalve molluscs, but there was no quantification of the relative importance of phototrophic nutrition versus filterfeeding until a study of Tridacna gigas L. by Klumpp et al. (1992). They showed that this clam is an efficient filter-feeder and that carbon derived from filterfeeding in Great Barrier Reef (GBR) waters supplies substantial proportions of the total carbon needed for respiration and growth. This proportion is size-dependent, decreasing from $65 \%$ in $42.5 \mathrm{~mm}$ shell length clams to $34 \%$ at $167 \mathrm{~mm}$ shell length.

The importance of filter-feeding in small Tridacna gigas raises the question of its contribution to the nutrition of other giant clam species, particularly $T$. tevoroa which occurs in deeper waters where light intensity is attenuated. There are 2 obvious mechanisms whereby $T$. tevoroa could extend down to greater depths than other tridacnid species: (1) it uses the low irradiance levels at those depths more efficiently for photosynthesis; (2) it relies increasingly on filter-feeding to supplement the deficient phototrophic nutrition at depths.

The fact that Tridacna derasa and T. tevoroa are closely related (Lucas et al. 1991) and co-occur, with the latter extending to greater depths, suggested that a comparison of filter-feeding, respiration and the photosynthesis-irradiance response in these 2 species could provide the key to the depth distribution of $T$. tevoroa.

\section{MATERIALS AND METHODS}

Maintenance and treatment of clams. The study was conducted at the Tonga Fisheries facilities, Sopu, Tongatapu Island. The facilities included a seawater system consisting of a series of large outdoor tanks supplied with a constant flow of unfiltered seawater, pumped from the adjacent reef/seagrass flats. This seawater system was used for conditioning clams and during the experiments. The study was conducted over the period July to October 1992 when seawater temperature ranged from 20 to $23^{\circ} \mathrm{C}$ at $09: 00 \mathrm{~h}$ and from 23 to $26^{\circ} \mathrm{C}$ at $14: 00 \mathrm{~h}$.

Tridacna tevoroa and $T$. derasa 300 to $500 \mathrm{~mm}$ in shell length (SL), hereafter termed 'large clams', were obtained from brood stock assembled by Tonga Fisheries. These brood stock originated from wild populations in Tonga, and were kept beyond the edge of the Sopu reef flat at ca $18 \mathrm{~m}$ depth. T. derasa 75 to $120 \mathrm{~mm}$ SL ('medium clams') were obtained from cultured stock kept on the Sopu reef flat at ca $3 \mathrm{~m}$ depth. Medium-sized $T$. tevoroa were not available. Small
(15 to $25 \mathrm{~mm}$ SL) specimens of both species were obtained from cultured stocks growing in outdoor concrete tanks $(2 \times 10 \times 3 \mathrm{~m}$ deep $)$ at the Sopu laboratory. The tanks were covered with translucent roofing, effectively reducing ambient sunlight by $10 \%$.

For experimental purposes, 1 outdoor tank was divided into 4 shading regimes using various grades of shade cloth. The percentages of surface irradiance, and their equivalent depth in coral reef waters, for the 4 shading regimes were: $83 \%=1.0 \mathrm{~m}$ or reef flat conditions; $46 \%=5 \mathrm{~m} ; 22 \%=15 \mathrm{~m} ; 11 \%=28 \mathrm{~m}$ (light extinction coefficients provided by B. E. Chalker, Australian Institute of Marine Science). In July 1992, clams from each of the size groups and species were distributed at random between these 4 light regimes and left for at least $2 \mathrm{wk}$ to acclimate before being used in clearance rate or respirometry measurements. The clam shells were brushed clean of epibionts before being placed in the tank. The shade cloth was also regularly brushed to maintain constant shade conditions. Clams were supported on mesh trays suspended just beneath the water surface, and supplied with constant flowing seawater and strong aeration.

Shell length was used as a general measure of size, while wet wt of the soft tissues was used as a measure of metabolising tissue. Clams of both species over the size range studied were sacrificed; their soft tissues were removed and weighed soon after death. Logarithmic relationships were determined between wet tissue wt and standard length for each species, and these were used to calculate wet tissue wt for specimens which were not sacrificed.

Respirometry. Two data-logging respirometers, as described by Klumpp et al. (1987), were used, each being able to monitor irradiance, temperature and oxygen flux in 4 replicate chambers at 1 min intervals. The respirometers were used to measure variations in dark respiration rates $(R)$ and net photosynthetic rate irradiance $(P-I)$ relationships for each clam species, size class and shading regime. Respirometers were immersed in a $1 \mathrm{~m}$ deep, $12000 \mathrm{l}$ capacity outdoor tank with running seawater. The usual monitoring protocol was to expose clams to natural variations of sunlight for ca $6 \mathrm{~h}$, combined with several hours in natural darkness to obtain respiration rate. Water in each chamber was completely and automatically replaced at 5 to 15 min intervals, and chamber volume could be varied between 2 and $57 \mathrm{l}$ depending on the size of clam. Shells of freshly-shucked clams were run as blanks.

$P$-I relationships for the 2 clam species under the 4 levels of shading were modelled using the hyperbolic tangent function (Jassby \& Platt 1976, Chalker 1981), as described in Klumpp et al. (1987) and Klumpp \& McKinnon (1989). This function gave the best fit to the 
$P-I$ data of this study $(\mathrm{r}>0.95, \mathrm{p}<0.001)$. Parameters used to describe the $P$-I response curve are: the

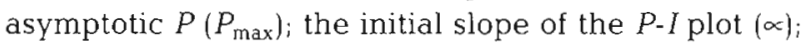
the irradiance at which $\propto$ intersects $P_{\max }\left(I_{k}\right)$; and the irradiance at which gross $P$ and $R$ are equal $\left(I_{c}\right.$, the compensation point). Thus $\propto$ is a measure of the efficiency of the $P$-I response, and $I_{k}$ is a standardised measure of the level of irradiance at which photosynthetic rate approaches the asymptote $\left(I_{95} \%\right.$ saturation $=$ $1.832 I_{k}$ for the hyperbolic tangent function).

Daily gross oxygen production $\left(P_{g}\right)$ by small and large clams of both species during winter and summer, and under the 4 simulated depths, was modelled by solving for $P$ of the relevant $P-I$ function over the $24 \mathrm{~h}$ cycle of irradiance expected at each depth. $P$ - $I$ functions were assumed not to vary between summer and winter. The $24 \mathrm{~h}$ irradiance cycle, which was divided into 15 min intervals, was derived from an extensive set of measurements by Klumpp \& McKinnon (1989) taken on cloudless days in summer and winter at Davies Reef, GBR. Measurements taken in Tonga gave similar light results. Daily oxygen consumption $\left(R_{24 \mathrm{~h}}\right)$ was calculated from $R$, assuming this to remain constant over day and night (see Klumpp et al. 1992). Daily net oxygen production was then derived as the difference between $P_{\mathrm{g}}$ and $R_{24} \mathrm{~h}$.

Clearance rate measurements. Clearance rates $(C R$, $\mathrm{l} \mathrm{h}^{-1}$ ) of clams, defined as volume of water cleared of particulate material per hour, were determined using a flow-through system in which water containing natural particulates at ambient concentrations was pumped continuously through 4 perspex chambers each containing a clam. From the flow rate $\left(F, l \mathrm{~h}^{-1}\right)$ and particle concentrations in the water entering $\left(C_{1}\right)$ and leaving $\left(C_{0}\right)$ each chamber, $C R$ is given as: $F\left(C_{1}-C_{0}\right) / C_{0}$. $C_{0}$ was used as the best approximation to the concentration immediately surrounding the clam (Hildreth \& Crisp 1976; for technical details see also Bayne et al. 1985, Klumpp et al. 1992).

In this study, $C_{1}$ was the particle concentration in the outlet water of a fifth chamber without a clam. A flow rate equivalent to at least 5 times the clearance rate of specimens was maintained to minimise recirculation of water by clams, and yet give detectable concentration differences (10 to $20 \%$ ) between control and test chambers. Tests with higher flows than this did not influence $C R$ (see Klumpp et al. 1992). Clams ranging in size from 15 to $515 \mathrm{~mm}$ were tested using chamber volumes of $120 \mathrm{ml}$ to $120 \mathrm{l}$. Concentration of particles within the size range 3 to $54 \mu \mathrm{m}$ was measured (mean of 4 counts) immediately after taking a sample, by means of a Coulter Counter (Model ZM) with a $140 \mu \mathrm{m}$ orifice tube.

After acclimation to shade conditions, clams were introduced to the chambers, which were supplied with a constant flow of seawater, and left undisturbed for a minimum of $4 \mathrm{~h}$ before commencing at least 5 replicate $C R$ measurements on each specimen at ca $30 \mathrm{~min}$ intervals.

Ingestion rates of clams were calculated as the product of $C R$ and concentration of particles in the water. It is assumed that all particles cleared from the water are ingested based on observations that clams do not produce pseudofaeces at particle concentrations occurring on coral reefs (Klumpp \& Hawkins unpubl. data). Food concentration was monitored in 20 separate 1 l water samples collected from both the reef/ seagrass flat and adjacent reef crest over the period of the study. Total particle concentrations within the size range 3 to $54 \mu \mathrm{m}$ were analysed using the Coulter Counter, and particulate organic carbon (POC) and particulate nitrogen ( $\mathrm{PN}$ ) of the acid-treated residues collected on pre-ashed GFF filters were analysed using an ANTEK C \& N analyser.

Growth rate of juveniles. Shell lengths of 50 juveniles of each species were measured and the clams were then placed in cavities on concrete slabs: the Tridacna tevorod on one slab and $T$. derasa on another. Cavities were in rows of 10 so that the juvenile clams were identifiable by their position on the slab, except for some that initially moved about before attaching with their byssus. This experiment commenced in August 1992 and, thereafter, the juveniles were measured at monthly intervals.

Data analysis. Because regression analysis showed that $C R, P_{\max }$ and $R$ varied markedly with clam size, variations in these parameters in relation to species and light level were examined using ANCOVA with clam size as the covariate. $I_{k}$ and $I_{\mathrm{c}}$ were independent of clam size (regression analysis), thus the effect of species and light regime on these parameters was tested using 2-way ANOVA. Where differences were significant, means were compared using the RyanEinot-Gabriel-Welsh test. All statistical analyses were performed using programs from SAS (1985).

\section{RESULTS}

\section{Photosynthesis and respiration}

Acclimation of a wide size range of clams to 4 light intensities ranging from 83 to $11 \%$ of surface irradiance had no significant effect on either maximum rate of net oxygen production $\left(P_{\max }\right)$ or dark oxygen consumption $(R)$ (ANCOVA, Table 1). Both $P_{\max }$ and $R$ were strongly correlated with clam size (Table 1 , Figs. 1 \& 2). Relationships between $P_{\max }$ and $R$ ( $\mu \mathrm{mol}$ $\mathrm{O}_{2} \min ^{-1}$ ) and size of clam (wet tissue wt, $W$, in $\mathrm{g}$ ) are described by the functions: 
Table 1. Tridacna spp. Summary of ANCOVA testing for similarity in clearance rate $(C R)$, maximum photosynthetic rate $\left(P_{\max }\right)$ and respiration rate $(R)$ across species of clam $(T$. derasa, T. tevoroa) and level of shading (equivalent to 83, 46 , $22,11 \%$ of surface irradiance) with wet tissue wt $(W)$ as the covariate. NS: not significant at $p<0.05_{i}{ }^{*} p<0.05_{i}{ }^{\cdots} p<0.01$; $\cdots p<0.0001$

\begin{tabular}{|lccc|}
\hline $\begin{array}{l}\text { Source of } \\
\text { variation }\end{array}$ & $C R$ & $\begin{array}{c}\text { Variate } \\
P_{\max }\end{array}$ & $R$ \\
\hline Weight $(W)$ & $\cdot$ & $\ldots$ & $\ldots$ \\
Species (Sp) & NS & NS & NS \\
Shading (Sh) & $\cdot$ & NS & NS \\
Sp $\times$ Sh & $\cdot$ & NS & NS \\
Sp $\times W$ & NS & NS & NS \\
Sh $\times W$ & NS & NS & NS \\
Sp $\times$ Sh $\times W$ & NS & NS & NS \\
& & & \\
\hline
\end{tabular}

\section{Tridacna derasa}

$\ln P_{\max }=-0.707+0.744 \ln W \quad\left(\mathrm{r}^{2}=0.98, \mathrm{n}=145\right) ;$

$\ln R=-2.101+0.736 \ln W \quad\left(\mathrm{r}^{2}=0.98, \mathrm{n}=145\right)$;

\section{T. tevoroa}

$\ln P_{\max }=-0.853+0.710 \ln W \quad\left(\mathrm{r}^{2}=0.98, \mathrm{n}=71\right) ;$

$\ln R=-2.188+0.726 \ln W \quad\left(\mathrm{r}^{2}=0.98, \mathrm{n}=71\right)$.

There was no significant difference between the size relationships of the 2 species (ANCOVA, Table 1). The exponents of the above relationships show a close approximation to the theoretical exponent of 0.67 expected for surface area (i.e. $P_{\max }$ or $R$ ) to volume (body mass) relationships. This is similar to the $R$ exponent of 0.755 for Tridacna gigas (Klumpp et al. 1992). Indeed, the average $R: W$ exponent value for bivalve molluscs is 0.7 (Bayne \& Newell 1983).

Another parameter which describes the $P$-I relationship is $I_{k}$, the irradiance at which $P$ approaches saturation. This did not vary significantly with size in either species (regression analysis, Table 2). However, $I_{k}$ did vary significantly (2-way ANOVA) between species $(p=0.044)$ and with irradiance level $(p=0.026)$. In Tridacna tevoroa, decreased levels of irradiance were accompanied by a progressive reduction in $I_{k}$ from 270 to $160 \mu \mathrm{E} \mathrm{m}^{-2} \mathrm{~s}^{-1}$ (Table 2), but irradiance had no significant influence on $I_{k}$ in $T$. derasa. Compensation irradiance, $I_{C}$, did not differ between species (ANOVA, $p=0.16$ ), but declined significantly with light intensity (ANOVA, $p=0.0001$ ), from $80 \mu \mathrm{E} \mathrm{m}^{-2} \mathrm{~s}^{-1}$ at $83 \%$ to $50 \mu \mathrm{E} \mathrm{m} \mathrm{m}^{-2} \mathrm{~s}^{-1}$ at $11 \%$ surface irradiance.

Daily gross oxygen production $\left(P_{\mathrm{g}}\right)$ of Tridacna tevoroa and $T$. derasa at the 4 light levels, or simulated depths, was estimated using the expected diel variation in irradiance at each depth on a typical coral reef and the known relevant $P$-I parameters (calculation of $P_{\mathrm{g}}$ is explained in 'Methods'). $R_{24} \mathrm{~h}$ was constant between species and across light levels (Table 1) and averaged

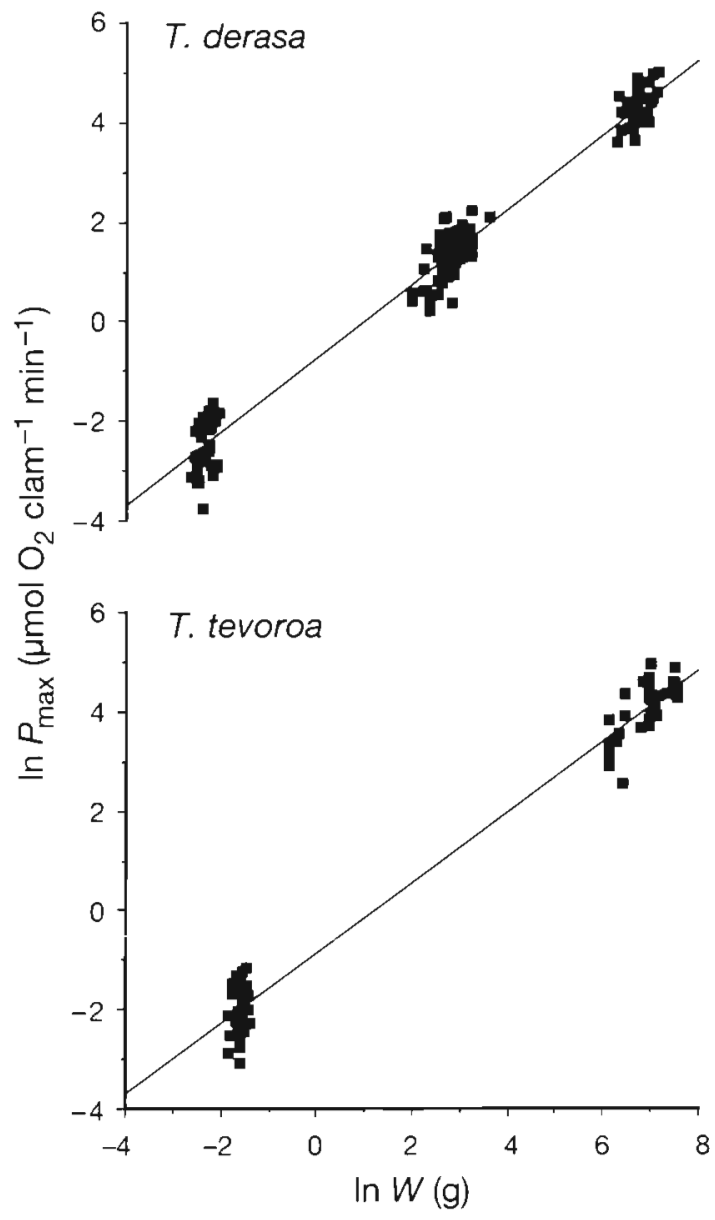

Fig. 1. Tridacna derasa, T. tevoroa. Relationship between maximum rate of net photosynthesis $\left(P_{\max }\right)$ and wet tissue wt $(W)$ for giant clams. Each data point is the rate for a single clam. Regression equations in text

$51.8 \mu \mathrm{mol} \mathrm{O} \mathrm{O}_{2} \mathrm{~d}^{-1}$ for small clams and $28.8 \mathrm{mmol} \mathrm{O}_{2} \mathrm{~d}^{-1}$ for large clams. The ratio $P_{\mathrm{g}}: R_{24 \mathrm{~h}}$ for both clam species on the reef flat in winter ranged from 1.4 in small clams to 1.5 in large clams, but these ratios declined to 0.5 and 0.8 , respectively, at a simulated depth of $28 \mathrm{~m}$ (Table 3). Reduction in $P_{\mathrm{g}}: R_{24 \mathrm{~b}}$ with depth was much less marked for $T$. tevoroa than for $T$. derasa.

The relationship of daily net oxygen production $\left(P_{n}=\right.$ $P_{\mathrm{g}}-R_{24 \mathrm{~h}}$ ) with transmitted irradiance, expressed as a proportion of surface irradiance, is illustrated for large clams $(W=850 \mathrm{~g}$ or $400 \mathrm{~mm} \mathrm{SL})$ in Fig. 3. This shows that in shallow reef flat conditions, $P_{n}$ of the 2 species are equivalent, but that net productivity of Tridacna tevoroa declines less rapidly than that of $T$. derasa as irradiance levels decrease with depth (Fig. 3). Thus in winter, $T$. tevoroa remains a net producer of oxygen $\left(P_{\mathrm{g}}>R_{24 \mathrm{~h}}\right)$ at irradiances exceeding $16 \%$ of surface levels, equivalent to $21 \mathrm{~m}$ depth on cloudless days. By comparison, T. derasa requires at least $27 \%$ of surface irradiance to maintain net productivity. This irradiance 


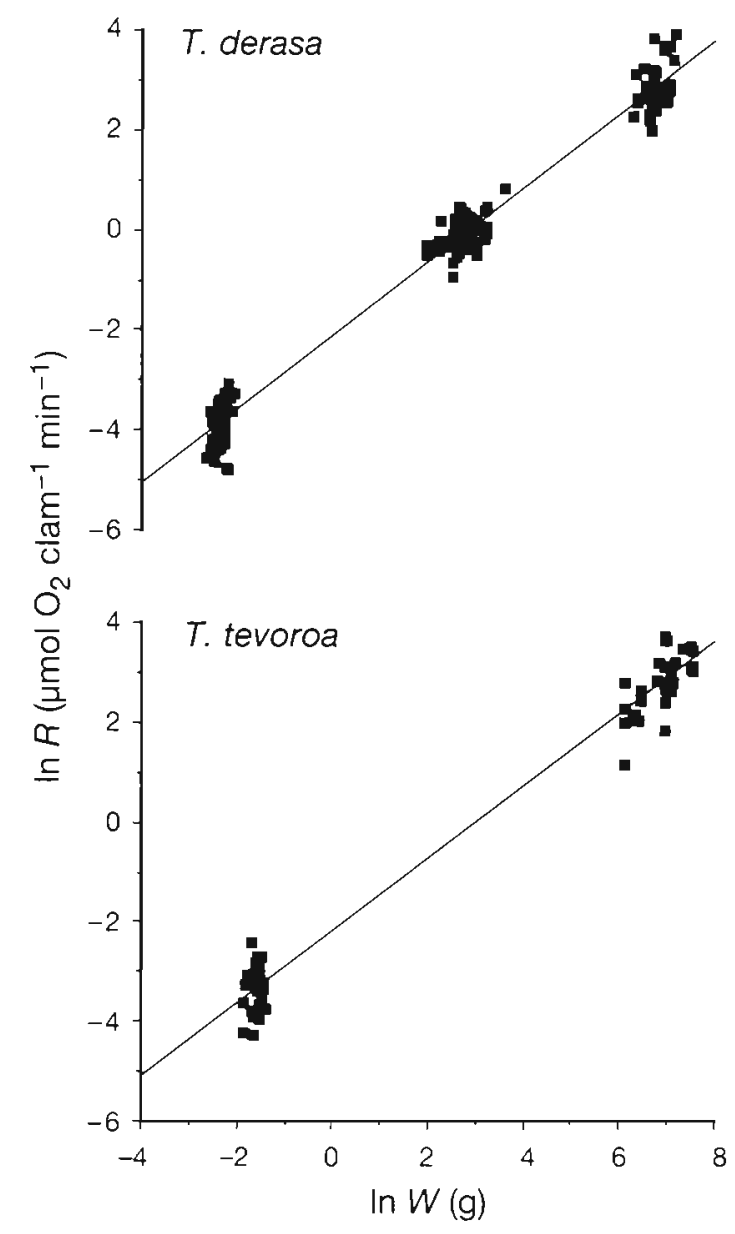

Fig. 2. Tridacna derasa, T. tevoroa. Relationships between respiration rate $(R)$ and wet tissue wt $(W)$ for giant clams. Each data point is the rate for a single clam. Regression equations in text

level is only achieved at less than $12 \mathrm{~m}$ depth. The equivalent compensation depths for large clams on cloudless summer days are $26 \mathrm{~m}$ or $12 \%$ of surface light for $T$. tevoroa, and $16 \mathrm{~m}$ or $21 \%$ of surface light for T. derasa (Fig. 3). Although not shown, the pattern is similar for small specimens $(W=0.2 \mathrm{~g})$, except that the compensation depths are consistently ca $2 \mathrm{~m}$ shallower than those of large clams.

\section{Contribution of photosynthates to host respiratory requirements}

Measurement of a positive net $24 \mathrm{~h}$ production of oxygen for clams at a particular depth does not mean that they can survive, let alone grow, at that depth. For this to occur we need at least to account for the utilisation of photosynthate by the symbiont and the efficiency of translocation to the host $(T)$. This is accounted for by calculating the percentage contribu- tion of algal (zooxanthellae) carbon to the host's daily requirements for routine respiration (called by convention $(Z A A R)$ using the formula:

CZAR $=$

$\frac{\left[\left(P_{\mathrm{n}, \text { ddy }} \times P Q^{-1} \times 0.375\right)+\left(R_{\text {day }} \times R Q \times 0.375\right)(0.95)\right] \times(\% T) \times 100}{R_{24 \mathrm{~h}} \times R Q \times 0.375 \times 0.95}$

as derived from Trench et al. (1981), where $P_{\mathrm{n} \text {, day }}=$ measured production during daylight; $R_{\text {day }}=$ respiration during daylight. It was assumed that $1 \mathrm{mg} \mathrm{O}_{2}=$ $0.375 \mathrm{mg} \mathrm{C}, R Q=0.8, P Q=1.0$, host $R=95 \%$ of the measured entire clam $R$ (see Klumpp et al. 1992), and $\% T=95 \%$ of photosynthate produced by algae is translocated to the host (see Muscatine 1990, Fitt 1993). From $R_{24 \mathrm{~h}}$ data, the daily routine respiratory requirements of the host tissues of Tridacna tevoroa and $T$. derasa in winter were estimated to be $472 \mu \mathrm{g}$ $\mathrm{C}$ for small clams and $262 \mathrm{mg} \mathrm{C}$ for large clams (Table 3). Converting $P_{g}$ to the gross amount of carbon translocated daily to host tissues shows that in the shallow reef flat habitat $840 \mu \mathrm{g} \mathrm{C}$ is available to small clams, compared with $491 \mathrm{mg} \mathrm{C}$ in large clams (Table 3). This is equivalent to 1.78 and 1.87 times the host's respiratory requirement, respectively. Clearly these results represent the maximum potential phototrophic contribution to nutrition, since $P_{\mathrm{g}}$ declines with depth, shading or cloudiness, while $R_{24 \mathrm{~h}}$ remains constant (Table 3 ). For example at $28 \mathrm{~m}$ depth $(11 \%$ surface irradiance; Table 3$), T$. tevoroa could satisfy 91 to $96 \%$ of its maintenance requirements from symbiont photosynthesis, depending on size, but $T$. derasa would receive only 59 to $62 \%$ of respiratory needs from this source.

Table 2. Tridacna spp. Relationships between $I_{k}$ and clam species, clam wet tissue wt $(W)$ and irradiance. Mean $I_{k}$ values are given for the 2 species of clam acclimated to 4 light regimes; significant differences between means are denoted by different letters after $I_{k}$ values (ANOVA, Ryan-EinotGabriel-Welsh test, $\mathrm{p}<0.05$ ). Results of regressions of $I_{k}$ on $W$ are presented as the slopes of lines and their $r^{2}$ values

\begin{tabular}{|ccccc|}
\hline $\begin{array}{l}\text { \% Surface } \\
\text { irradiance }\end{array}$ & $I_{k}$ & $\mathrm{n}$ & Slope & $\mathrm{r}^{2}$ \\
\hline \multicolumn{2}{l}{ Tridacna derasa } \\
83 & $262 \mathrm{a}$ & 43 & -0.09 & 0.03 \\
46 & $254 \mathrm{a}$ & 33 & -0.19 & 0.16 \\
22 & $244 \mathrm{a}$ & 29 & -0.04 & 0.07 \\
11 & $238 \mathrm{a}$ & 40 & -0.09 & 0.03 \\
\multicolumn{7}{l}{ Tridacna tevoroa } & & & \\
83 & $269 \mathrm{a}$ & 16 & -0.03 & 0.03 \\
46 & $209 \mathrm{~b}$ & 13 & -0.05 & 0.23 \\
22 & $176 \mathrm{c}$ & 23 & -0.08 & 0.32 \\
11 & $160 \mathrm{c}$ & 19 & 0.00 & 0.00 \\
\hline
\end{tabular}


Table 3. Tridacna spp. Daily gross oxygen production $\left(P_{\mathrm{g}}\right.$ in $\mu \mathrm{mol} \mathrm{O}_{2}$ for small clams and $\mathrm{mmol} \mathrm{O}_{2}$ for large clams), ratio of daily oxygen production to respiration $(P / R)$, daily translocated carbon production $(T P$ in $\mu \mathrm{g} C$ for small clams and mg $C$ for large clams), and $T P$ as a percentage of daily routine respiratory requirements (CZAR). Results are presented for small $(0.2 \mathrm{~g})$ and large $(850 \mathrm{~g})$ specimens of clams at 4 simulated depths in winter. Daily respiration $(R)$ was $51.8 \mu$ mol $\mathrm{O}_{2}$ in small clams and $28.8 \mathrm{mmol} \mathrm{O}_{2}$ in large clams for all species and depths. Conversion of oxygen to carbon is explained in 'Results'

\begin{tabular}{|c|c|c|c|c|c|c|c|c|c|}
\hline \multirow{2}{*}{$\begin{array}{l}\% \text { Surface } \\
\text { irradiance }\end{array}$} & \multirow[t]{2}{*}{ Depth (m) } & \multicolumn{4}{|c|}{ Large clams } & \multicolumn{4}{|c|}{ Small clams } \\
\hline & & $P_{\mathrm{g}}$ & $P / R$ & $T P$ & CZAR & $P_{\mathrm{g}}$ & $P / R$ & $T P$ & CZAR \\
\hline \multicolumn{10}{|c|}{ Tridacna derasa } \\
\hline 83 & 1 & 43.1 & 1.50 & 491 & 187 & 73.7 & 1.42 & 840 & 178 \\
\hline 46 & 5 & 37.1 & 1.29 & 423 & 161 & 63.6 & 1.23 & 725 & 154 \\
\hline 22 & 15 & 25.3 & 0.88 & 288 & 110 & 43.2 & 0.83 & 492 & 104 \\
\hline 11 & 28 & 14.4 & 0.50 & 164 & 63 & 24.6 & 0.47 & 280 & 59 \\
\hline \multicolumn{10}{|c|}{ Tridacna tevoroa } \\
\hline 83 & 1 & 43.1 & 1.50 & 491 & 187 & 73.7 & 1.42 & 840 & 178 \\
\hline 46 & 5 & 39.9 & 1.39 & 455 & 174 & 68.3 & 1.32 & 778 & 168 \\
\hline 22 & 15 & 32.3 & 1.12 & 368 & 140 & 55.3 & 1.07 & 630 & 133 \\
\hline 11 & 28 & 22.0 & 0.76 & 251 & 96 & 37.6 & 0.73 & 428 & 91 \\
\hline
\end{tabular}

\section{Comparative growth rates in juveniles}

Growth rates measured from shell lengths (SL) of juvenile Thdacna derasa and $T$. levorua weìe esseñtially linear over the 8 mo measurement period (Fig. 4; regression slopes $=4.7 \mathrm{~mm} \mathrm{mo}^{-1}, \mathrm{r}^{2}=0.98, \mathrm{n}=40$ for $T$. derasa; $4.2 \mathrm{~mm} \mathrm{mo}^{-1}, \mathrm{r}^{2}=0.98, \mathrm{n}=38$ for $T$. tevoroa) These growth rates apply approximately to clams in our small to medium size categories, but not to larger specimens in which growth normally slows with the onset of sexual maturity (see Lucas in press). There was no significant difference between the growth rates of juvenile $T$. derasa and $T$. tevoroa (Fig. 4), thus an average shell growth rate of $4.5 \mathrm{~mm} \mathrm{mo}^{-1}\left(0.15 \mathrm{~mm} \mathrm{~d}^{-1}\right)$ was used in further calculations. This growth rate is close to reported values of ca $5 \mathrm{~mm} \mathrm{mo}^{-1}$ for $T$. derasa in Fijian waters (Adams et al. 1988).

Daily weight increments were calculated from measured growth in SL and our regressions of wet tissue wt ( $W, g)$ on SL:

Tridacna derasa

$$
\begin{aligned}
& \ln W=2.852 \ln \mathrm{SL}-10.361 \\
& \left(\mathrm{r}^{2}=0.99, \mathrm{n}=24\right)
\end{aligned}
$$

\section{T. tevoroa}

$\ln W=2.811 \ln \mathrm{SL}-10.047$

$$
\left(r^{2}=0.99, n=32\right) \text {. }
$$

These calculations showed that small clams with $W=0.2 \mathrm{~g}$ (equivalent to $21.51 \mathrm{~mm}$ $\mathrm{SL}$ for $T$. derasa and $20.12 \mathrm{~mm} \mathrm{SL}$ for $T$. tevoroa) are growing at $4.0 \mathrm{mg} \mathrm{d}^{-1}$ and $4.3 \mathrm{mg} \mathrm{d}^{-1}$, respectively. These growth rates are equivalent to $32-34 \mu \mathrm{N} \mathrm{d}^{-1}$ and $124-133 \mu \mathrm{g} \mathrm{C} \mathrm{d}^{-1}$ (dry wt $=10 \%$ of wet wt, from this study; clam dry tissues are $8 \% \mathrm{~N}$ and $31 \%$ C, from Klumpp et al. 1992).

\section{Clearance rate and ingestion of particulate matter}

The rates at which Tridacna derasa and $T$. tevoroa clearcd ambient water of suspended particles depended very strongly on body size (Fig. 5, Table 4). Slopes of the regressions of $C R$ on body size did not vary between species or with light level (Table 1; ANCOVA: $\mathrm{Sp} \times W$, Sh $\times W$ interactions), but light level and species appeared to have a significant effect on weight-specific $C R$ (i.e. intercepts; see Table 1). Removal of the $11 \%$ surface irradiance $T$. tevoroa data set from the analysis showed that the effect was due to this treatment alone. Thus $C R$ of $T$. derasa was not significantly affected by the 3 levels of irradiance, and was identical to that of $T$. tevoroa under all light levels except $11 \%$ surface irradiance, where the $C R$ of small $T$. tevoroa was relatively low.

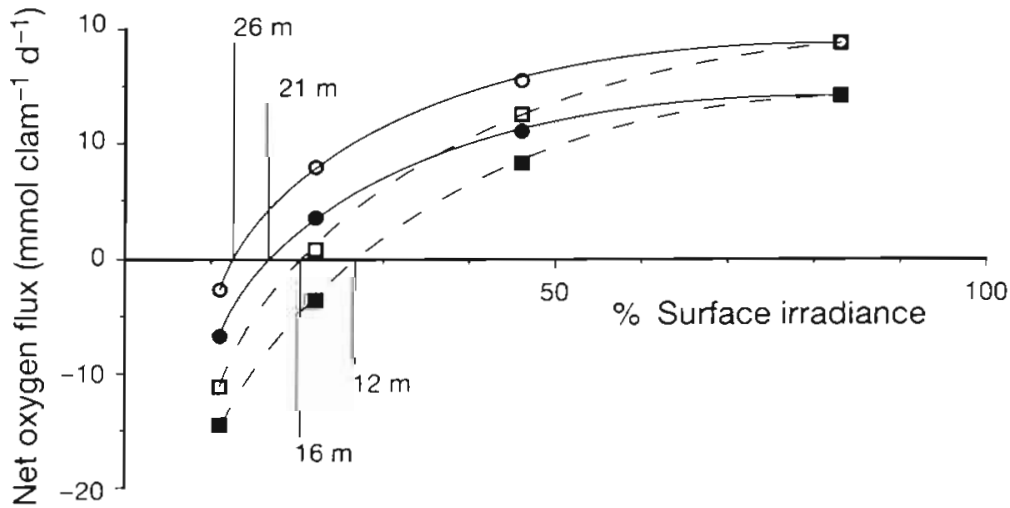

Fig. 3. Tridacna spp. Variation in daily net oxygen flux (net production or consumption) of large $T$. derasa (squares) and $T$. tevoroa (circles) with irradiance expressed as a percentage of surface irradiance on cloudless days in winter (solid symbols) and summer (open symbols). The equivalent depths (m) where net production is zero (compensation depths) are indicated 


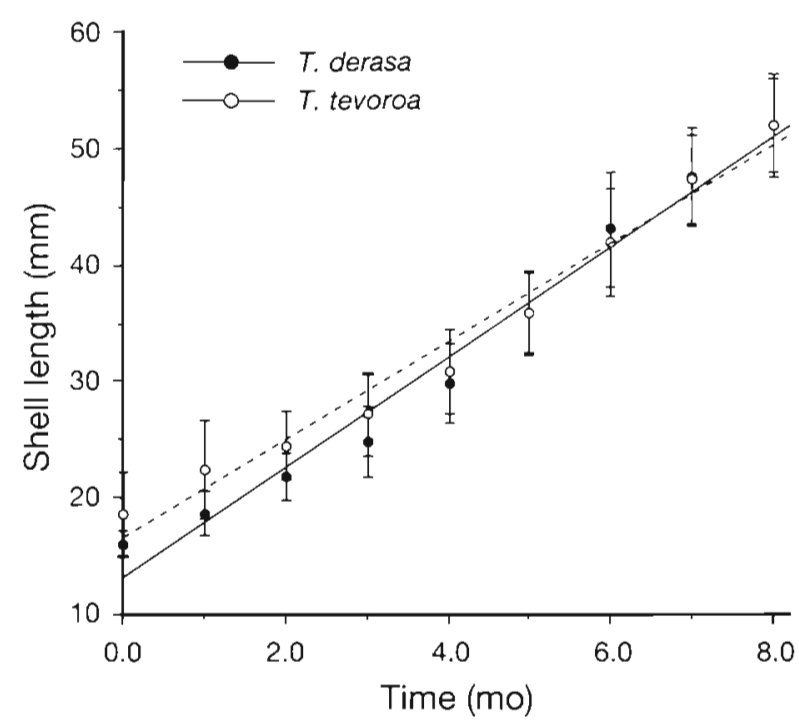

Fig. 4. Tridacna spp. Growth in shell length of juvenile giant clams held in the seawater system at Tonga Fisheries, Sopu, from August 1992 to April 1993

Ingestion rates of clams (in $\mu$ g organic $\mathrm{C}$ or $\mathrm{N} \mathrm{h}^{-1}$ ) were calculated as the product of $C R$ and concentration of suspended particles ( $\mu \mathrm{g}$ organic $\mathrm{C}$ or $\mathrm{N}^{-1}$ ) Seawater supplied to the $C R$ chambers from the reef/ seagrass flat had an average suspended particle concentration of 6200 particles $\mathrm{ml}^{-1}$, while POC and PN averaged $358 \mu \mathrm{g} \mathrm{C} \mathrm{l}^{-1}$ and $51 \mu \mathrm{g} \mathrm{N} \mathrm{l}^{-1}$, respectively. Adjacent reef waters, where clam brood stocks were maintained, contained $65 \mu \mathrm{g} \mathrm{Cl}^{-1}$ and $11 \mu \mathrm{g} \mathrm{N} \mathrm{l}^{-1}$. This level of POM is within the range reported in other nonoceanic reef waters (see Klumpp et al. 1992). In calculating ingestion rates of Tridacna derasa and $T$. tevoroa, we used the average of $C R$-size relationships for clams in shallow water $183 \%$ surface irradiance, Table 4: slope 0.69 , intercept 0.78 ) and an average particulate concentration of $65 \mu \mathrm{g} \mathrm{Cl}^{-1}$ and $11 \mu \mathrm{g} \mathrm{N} \mathrm{l}^{-1}$. Thus, small ( $W=0.2 \mathrm{~g})$ and large $(W=850 \mathrm{~g}$ wet tissue wt) clams on the reef around Sopu clearing water at rates of $1.03 \mathrm{l} \mathrm{d}^{-1}$ and $330 \mathrm{l} \mathrm{d}^{-1}$, respectively, would ingest $67 \mu \mathrm{g} \mathrm{C} \mathrm{d}^{-1}$ and $21.5 \mathrm{mg} \mathrm{C} \mathrm{d}^{-1}$. If all ingested material was absorbed, intake of carbon from this filter-feeding would satisfy $14 \%$ and $8 \%$ of the respiratory requirements of small and large clams respectively. Absorption efficiencies were not determined for T. derasa and T. tevoroa, but 3 other tridacnid species absorbed 50 to $60 \%$ of ingested reef particles (Klumpp et al. 1992, Klumpp \& Griffiths unpubl. data). Daily intake of nitrogen from filter-feeding would range from $11 \mu \mathrm{g} \mathrm{N} \mathrm{d}^{-1}$ in small clams to $3.63 \mathrm{mg} \mathrm{N} \mathrm{d}^{-1}$ for large clams. The measured growth rates of small clams were equivalent to 32 to $34 \mu \mathrm{g} \mathrm{N} \mathrm{d}^{-1}$ and, hence, a maximum $33 \%$ of the nitrogen deposited in tissues of small clams could be derived from ingestion of PON.

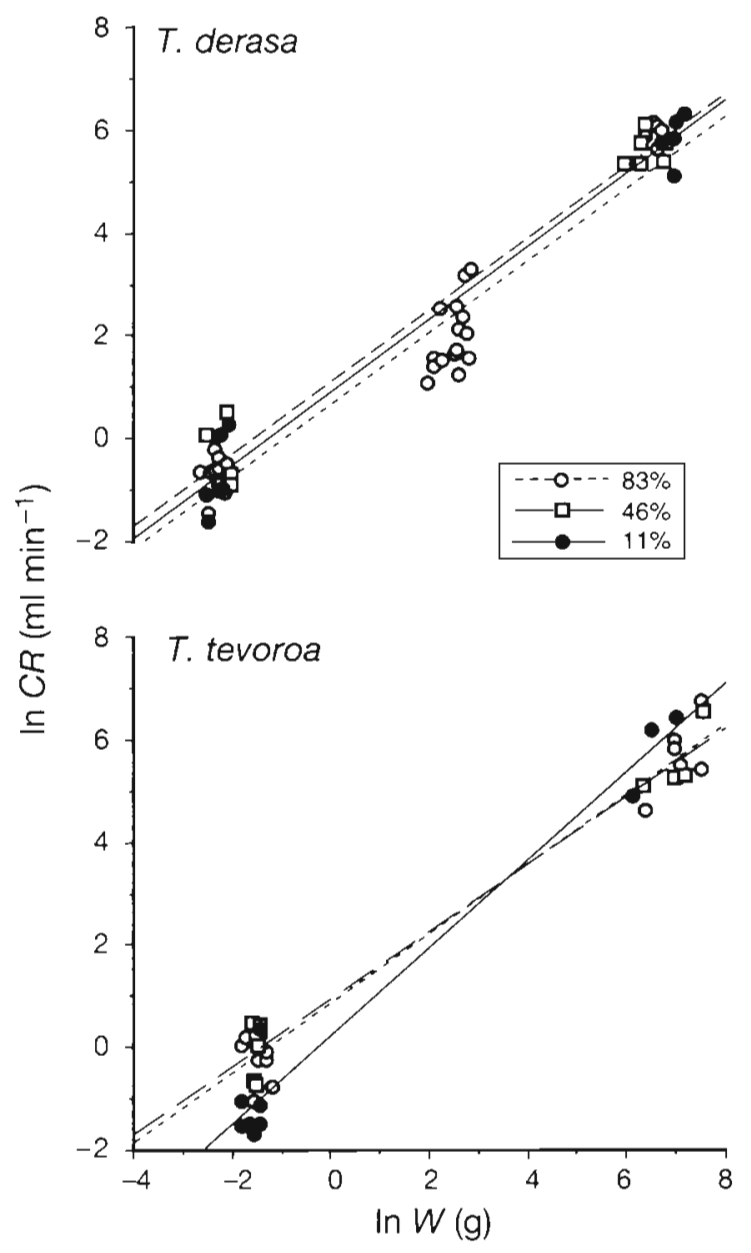

Fig. 5. Tridacna spp. Relationship between clearance rate $(C R)$ and wet tissue wt $(W)$ for $T$. derasa and $T$. tevoroa acclimated to 3 light regimes, equivalent to 83,46 and $11 \%$ of surface irradiance. Each data point is the rate for a single clam. Regression equations given in Table 4

Table 4. Tridacna spp. Relationships between clearance rate $\left(C R, \mathrm{ml} \mathrm{clam}{ }^{-1} \mathrm{~min}^{-1}\right)$ and wet tissue wt $(W, \mathrm{~g})$ of clams acclimated to 3 light regimes $(83,46$ and $11 \%$ of surface irradiance). Data are presented as the slopes and intercepts from linear regressions of $\ln C R$ against $\ln W$ (see Fig. 5)

\begin{tabular}{|c|c|c|c|c|}
\hline $\begin{array}{l}\% \text { Surface } \\
\text { irradiance }\end{array}$ & Slope & Intercept & $r^{2}$ & $\mathrm{n}$ \\
\hline \multicolumn{5}{|c|}{ Tridacna derasa } \\
\hline 83 & 0.70 & 0.68 & 0.92 & 30 \\
\hline 46 & 0.70 & 1.12 & 0.98 & 12 \\
\hline 11 & 0.71 & 0.91 & 0.98 & 12 \\
\hline \multicolumn{5}{|c|}{ Tridacna tevoroa } \\
\hline 83 & 0.68 & 0.88 & 0.97 & 16 \\
\hline 46 & 0.66 & 0.97 & 0.97 & 10 \\
\hline 11 & 0.86 & 0.24 & 0.97 & 10 \\
\hline
\end{tabular}




\section{DISCUSSION}

\section{Comparative nutrition of Tridacna tevoroa and $T$. derasa}

This study provides the first quantification of the nutrition of the little-known giant clam Tridacna tevoroa which was recently discovered inhabiting relatively deep (range 9 to $33 \mathrm{~m}$, mean 26 to $27 \mathrm{~m}$ ) and clear oceanic waters off Tonga and Fiji (see Lucas et al. 1991, Ledua et al. 1993). We have compared it with the closely related sympatric $T$. derasa, which occurs down to $20 \mathrm{~m}$ but is more common in shallower waters, especially in the juvenile stage (Adams et al. 1988). These comparisons show that the 2 clam species function identically in shallow waters $(<2 \mathrm{~m})$ both in terms of filtration rate and the relationship between irradiance and net primary production. However, T. tevoroa is able to maintain its photosynthetic capabilities at lower light intensities than $T$. derasa and is hence able to maintain energy balance at approximately $10 \mathrm{~m}$ greater depth (see Fig. 3 , Table 3). This corresponds well with the known depth distributions of the 2 species (Ledia et al. 1993). Under increasing simulated depths, $T$. tevoroa somehow increases the efficiency of its photosynthetic-irradiance response. With decreasing irradiance, the $P$ - $I$ parameters $I_{k}$ and $I_{c}$ decreased, $\propto$ increased, while $R$ and $P_{\text {max }}$ remained constant. At sub-saturating light intensities, this species thus photosynthesises at a significantly greater rate than $T$. derasa, which showed no evidence of photoadaptation under reduced light intensities.

Several unique morphological adaptations, likely to facilitate the utilisation of reduced light intensities in $T r i$ dacna tevoroa, were noted by Lucas et al. (1991). These are the rugose mantle, unusually wide gape of the valves, paucity of iridophores and shallow distribution of zooxanthellae in the mantle tissue. The first 2 features should increase available surface for zooxanthellae, while the last 2 features should maximise transmittance of light to these cells. Lucas et al. (1991) further proposed that photoadaptation by zooxanthellae may be important in $T$. tevoroa based on experimental evidence for such photoadaptation in T. gigas (Mingoa 1988). Work primarily on corals has shown that photoadaptation by zooxanthellae may be effected through alterations to the quantity and size of the light-capturing apparatus of chloroplasts or photosynthetic units, and thus the chlorophyll a concentration, as well as the rates of associated chemical reactions (see Dustan 1982, Chang et al. 1983). Of these, increase in photosynthetic unit size as a photoadaptive response has been identified in T. maxima (Chang et al. 1983). This is consistent with the recent observation of a doubling in chlorophyll a concentration per zooxanthellae in juvenile T. gigas kept under 90\% shading (Mingoa 1988, 1990).

\section{Nutritional roles of phototrophy and filter-feeding in clams}

We have sufficient data to compare the contributions made by phototrophy and filter-feeding to the nutritional requirements (growth plus respiration) of the giant clam species tested. Small Tridacna derasa and $T$. tevoroa from Tonga respire carbon at a rate of $470 \mu \mathrm{g} \mathrm{C} \mathrm{d}^{-1}$, and phototrophy provides considerably more than this under cloudless, reef flat conditions

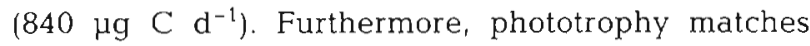
respiratory needs at the respective depth limits of each species (20 $\mathrm{m}$ and $30 \mathrm{~m}$; Table 3 ). The amount of carbon derived from phototrophy would, however, decline under cloudy conditions. Trench et al. (1981) measured a $50 \%$ reduction in irradiance under cloudy conditions on a coral reef, and this reduced the contribution of phototrophy to respiratory carbon demand by $20 \%$ in 2 specimens of $T$. maxima. Assuming that clouds cause a similar shading in Tongan reef waters, it is apparent from Table $3(46 \%$ surface irradiance $=$ $5 \mathrm{~m}$ depth) that $T$. derasa and $T$. tevoroa under cloudy conditions on the reef flat could still satisfy 155 to $175 \%$ of respiratory needs via phototrophy.

Other species of giant clam also appear to derive a high proportion of their respiratory carbon needs from zooxanthellae, even under cloudy conditions. Equivalent CZAR figures for Tridacna gigas vary from 73 to $126 \%$ (Fisher et al. 1985, Mingoa 1988, Klumpp et al. 1992) and for T. maxima from 63 to $84 \%$ (Trench et al. 1981). It must be emphasised that all of these estimates were based on the assumption that only 30 to $40 \%$ of carbon production was translocated to the host. However, recent reviews of symbiotic associations in reef corals and clams conclude that these are serious underestimates and that translocation efficiency is 78 to $98 \%$ for corals (Muscatine 1990) and 90 to $95 \%$ for clams (Fitt 1993). Given this, recalculated CZAR values for all giant clam species examined to date would be well in excess of $100 \%$. This aside, comparison of daily oxygen flux in T. gigas (Klumpp et al. 1992) with those of $T$. tevoroa and $T$. derasa, using the same techniques and under similar environmental conditions (cloudless, winter, reef flat), reveals interesting differences in their metabolism. While gross oxygen production standardised to size is the same for all 3 species, rates of oxygen consumption are significantly higher in $T$. derasa and $T$. tevoroa. For example, $66 \mathrm{~mm}$ SL $T$. gigas produced $28.8 \mathrm{mg} \mathrm{O}_{2}$ daily and consumed $8.2 \mathrm{mg} \mathrm{O}_{2}$, i.e. a $P: R$ ratio of 3.5 (Table III in Klumpp et al. 1992), compared with the production of $30 \mathrm{mg} \mathrm{O}$ and consumption of $19.9 \mathrm{mg} \mathrm{O} 2(P: R$ of 1.5$)$ in the same sized $T$. tevoroa and $T$. derasa (Table 3 ).

The rapid growth of tridacnid clams compared with most other bivalve molluscs has been shown to be 
based on their ability to access substantial food resources in the form of both POM and photosynthate and to allocate a high proportion of this energy to growth (Klumpp et al. 1992). These authors showed that $T$. gigas, the largest and fastest-growing giant clam species, deposited as much carbon in tissues as it respired. In contrast $T$ tevoroa and $T$. derasa expended more energy in respiration and utilised only $22 \%$ of carbon for growth $\left(G: 130 \mu \mathrm{g} \mathrm{C} \mathrm{d}^{-1}, R: 470 \mu \mathrm{g} \mathrm{C} \mathrm{d}^{-1}\right.$ in small clams). This is similar to typical non-symbiotic bivalves in which G:R ratios average $1: 3$ or $25 \%$ (Bayne \& Newell 1983).

Our experimental results indicate that under optimum light conditions (sunny, shallow waters), phototrophy more than satisfies (140\%) the daily carbon requirements for both maintenance and growth (i.e. $600 \mu \mathrm{g} \mathrm{C}$ ) in rapidly growing small Tridacna tevoroa and $T$. derasa. However, this needs to be assessed in the context of the natural distributions of these clams. In Fijian waters, juvenile $T$. derasa (up to $310 \mathrm{~mm}$ ) are usually found loosely attached to coral on the tops and sides of shallow coral outcrops (Adams et al. 1988). They thus experience optimal phototrophic conditions and should be able to maintain their rapid growth solely on the carbon derived from symbiosis (Table 3 ). Large $T$. derasa are found down to $20 \mathrm{~m}$ in clear oceanic conditions; but it is thought that they have fallen there as adults following detachment of their byssus. These adults grow more slowly (Adams et al. 1988, Lucas in press), and the results of Table 3 suggest that they probably receive sufficient energy from phototrophy. Thus, the carbon budget for this species can be balanced from phototrophy alone.

Juvenile Tridacna tevoroa have never been found in nature, which is not surprising given the rarity of this clam. However, from what is known of the distribution of adults in Fiji and Tonga, it appears that juveniles settle on slopes of off-shore reefs in deep (down to $33 \mathrm{~m}$ ) oceanic waters (Lewis \& Ledua 1988, Ledua et al. 1993). Comparison of the balance between growth and maintenance requirements $\left(600 \mu \mathrm{g} \mathrm{C} \mathrm{d} \mathrm{d}^{-1}\right.$ in small clams) and the potential contribution of photosynthate indicates that this species cannot rely entirely on phototrophy at the deeper limits of its distribution. For example, at $28 \mathrm{~m}$ depth, $T$. tevoroa acquires a maximum of $428 \mu \mathrm{g} \mathrm{C} \mathrm{d} \mathrm{d}^{-1}$ (Table 3) or $70 \%$ of its total carbon needs from phototrophy, and thus must utilise alternative, heterotrophic sources of energy.

Apart from phototrophy, clams can obtain nutrition from filter-feeding (Morton 1978, Reid et al. 1984a, Fankboner \& Reid 1990), possible digestion of zooxanthellae in the digestive tract (not in the kidney, e.g. as discussed by Reid et al. 1984b), and uptake of dissolved organic molecules (Fankboner 1971, Goreau et al. 1973, see review by Fitt 1993). While giant clams probably do take up dissolved organic matter (DOM) (Goreau et al. 1973), the nutritional value of this and the digestion of zooxanthellae have never been quantified. Filter-feeding, however, is now known to be a significant source of nutrition in Tridacna gigas, especially in juveniles (Klumpp et al. 1992). These authors calculated that filter-feeding in GBR waters can supply $65 \%$ of requirements for growth and respiration in a $42 \mathrm{~mm} T$. gigas, decreasing to $34 \%$ at $167 \mathrm{~mm}$. In contrast, filter-feeding provides relatively little carbon to both $T$. tevoroa and $T$. derasa, contributing at most $8 \%$ and $14 \%$ of respiratory carbon demands of large and small clams, respectively.

The apparent differences between the contributions of filter-feeding in Tridacna gigas relative to $T$. tevoroa and $T$. derasa are partly due to the higher levels of POM available in GBR waters compared to Sopu reef (97 $\mu \mathrm{g} \mathrm{Cl}^{-1} \mathrm{cf} .65 \mu \mathrm{g} \mathrm{Cl}^{-1}$ ), and the interspecific differences in respiration rates described above. However, the main difference is the much slower clearance rates of $T$. tevoroa and $T$. derasa (ca $1 \mathrm{l} \mathrm{d}^{-1}$ for small clams) compared with equivalent-sized $T$. gigas (ca $7 \mathrm{l} \mathrm{d}^{-1}$ ) at similar temperature. This greater reliance on filterfeeding in $T$ gigas may be reflected in various distinctive features of its gills, including it being the only tridacnid species with both dorsal and ventral demibranch food grooves (Norton \& Jones 1992).

In conclusion, a range of nutritional strategies is apparent from these studies. Tridacna derasa is able to function as a complete autotroph in its natural habitat (down to $20 \mathrm{~m}$ ), and $T$. tevoroa achieves this in the shallower parts of its distribution (10 to $20 \mathrm{~m}$ ). T. gigas shows a different strategy, comfortably satisfying all apparent carbon requirements from the combined sources of filter-feeding and phototrophy (Klumpp et al. 1992). Despite the increased efficiency of its photosynthetic-irradiance response, at the deeper limits to its distribution (ca $30 \mathrm{~m}$ ), T. tevoroa must access other sources of nutrition, such as DOM, in order to supplement particulate matter and photosynthate which can provide a maximum $83 \%$ of nutritional requirements.

Acknowledgments. We thank the Ministry of Fisheries Tonga, and, in particular, the Director, Mr Sione Mangesi, for providing facilities for this study. We thank Tonga Fisheries and JICA staff who provided help in the collection and maintenance of specimens, in setting up experiments, and with growth data. Funding support was provided by the Australian Centre for International Agricultural Research. Coulter Electronics Pty Ltd of Sydney generously loaned the particle counter. J.S.L. was on a Special Studies Program from James Cook University. We are especially grateful to Helen Lucas and Eve Klumpp whose help with monitoring experiments allowed us to proceed under difficult conditions. Charles Griffiths provided helpful comments on a draft of the manuscript. This is AIMS Contribution No. 664 


\section{LITERATURE CITED}

Adams, T. J. H., Lewis, A. D., Ledua, E. (1988). Natural population dynamics of Tridacna derasa in relation to reef reseeding and mariculture. In: Copland, J. W., Lucas, J. S. (eds.) Giant clams in Asia and the Pacific, ACIAR Monograph No. 9. Australian Centre for International Agricultural Research, Canberra, p. 78-81

Bayne, B. L., Brown, D. A., Burns, K., Dixon, D. R., Ivanovici, A., Livingstone, D. R., Lowe, D. M., Moore, M. N., Stebbing, A. D., Widdows, J. (1985). Physiological procedures In: The effects of stress and pollution on marine animals Praeger, New York, p. 166-167

Bayne, B. L., Newell, R. C. (1983). Physiological energetics of marine molluscs. In: Wilbur, K. M. (ed.) The Mollusca Vol. 4. Academic Press, New York, p. 407-515

Chalker, B. E. (1981). Simulating light-saturation curves for photosynthesis and calcification by reef-building corals. Mar. Biol. 63: 135-141

Chang, S. S., Prezelin, B. B., Trench, R. K. (1983). Mechanisms of photoadaptation in three strains of the symbiotic dinoflagellate Symbiodinium microadriaticum. Mar. Biol. 76: $219-229$

Dustan, P. (1982). Depth dependent photoadaptation by zooxanthellae of the reef coral Montastrea annularis. Mar. Biol, 68: 253-264

Fankboner, P. V (1971). Intracellular digestion of symbiotic zooxanthellae by host amoebocytes in giani ciams (Bivalvia: Tridacnidae), with a note on the role of the hypertrophied siphonal epidermis. Biol. Bull. 141: 222-234

Fankboner, P. V., Reid, T. G. B. (1990). Nutrition in giant clams (Tridacnidae). In: Morton, B. (ed.) The Bivalvia proceedings of a memorial symposium in honour of Sir Charles Maurice Yonge, Edinburgh, 1986. Hong Kong Univ. Press, Hong Kong, p. 195-209

Fisher, C. R., Fitt, W. K., Trench, R. K. (1985). Photosynthesis and respiration in Tridacna gigas as a function of irradiance and size. Biol. Bull. 169: 230-245

Fitt, W. K. (1993). Nutrition of giant clams. In: Fitt, W. K. (ed.) Biology and mariculture of giant clams, ACIAR Proceedings No. 47. Australian Centre for International Agricultural Research, Canberra, p. 31-40

Goreau, T. F., Goreau, N. I., Yonge, C. M. (1973). On the utilisation of photosynthetic products from zooxanthellae and of a dissolved amino acid in Tridacna maxima $f$. elongata (Mollusca: Bivalvia). J. Zool., Lond. 169: 417-454

Hildreth, D. I., Crisp, D. J. (1976). A corrected formula for calculation of filtration rate of bivalve molluscs in an experimental flowing system. J. mar. biol. Ass. U.K. 56: 111-120

Jassby, A. D., Platt, T. (1976). Mathematical formulation of the relationship between photosynthesis and light for phytoplankton. Limnol. Oceanogr. 21: 540-547

Klumpp, D. W., Bayne, B. L., Hawkins, A. J. S. (1992). Nutrition of the giant clam Tridacna gigas (L.). I. Contribution of filter feeding and photosynthates to respiration and growth. J. exp. mar. Biol. Ecol. 155: 105-122
Klumpp, D. W., McKinnon, D., Daniel, P. (1987). Damselfish territories: zones of high productivity on coral reefs. Mar. Ecol. Prog. Ser 40: 41-51

Klumpp, D. W., McKinnon, A. D. (1989). Temporal and spatial patterns in primary production of a coral-reef epilithic algal community. J. exp. mar. Biol. Ecol. 131: 1-22

Ledua, E., Manu, N., Braley, R. D. (1993). Distribution, habitat and culture of the recently described giant clam Tridacna tevoroa in Fiji and Tonga. In: Fitt, W. K. (ed.) Biology and mariculture of giant clams, ACIAR Proceedings No. 47. Australian Centre for International Agricultural Research, Canberra, p. 147-153

Lewis, A. D., Ledua, E. (1988). A possible new species of Tridacna (Tridacnidae: Mollusca) from Fiji. In: Copland, J. W., Lucas, J. S. (eds.) Giant clams in Asia and the Pacific, ACIAR Monograph No. 9. Australian Centre for International Agricultural Research, Canberra, p. 82-85

Lucas, J. S. (in press). The biology, exploitation, and mariculture of giant clams (Tridacnidae). Rev. Fish. Sci.

Lucas, J. S., Ledua, E., Braley, R. D. (1991). Tridacna tevoroa Lucas, Ledua and Braley: a recently-described species of giant clam (Bivalvia; Tridacnidae) from Fiji and Tonga. Nautilus 105: 92-103

Mingoa, S. M. (1988). Photoadaptation in juvenile Tridacna gigas. In: Copland, J. W., Lucas, J. S. (eds.) Giant clams in Asia and the Pacific, ACIAR Monograph No. 9. Australian Centre for International Agricultural Research, Canberra, p. $145-150$

Mingoa, S. M. (1990). The influence of environmental factors on juvenile Tridacna gigas. Ph.D. thesis, James Cook University of North Queensland

Morton, B. (1978). The diurnal rhythm and the process of feeding and digestion in Tridacna crocea (Bivalvia: Tridacnidae). J. Zool., Lond. 185: 371-387

Muscatine, L. (1990). The role of symbiotic algae in carbon and energy flux in reef corals. In: Dubinsky, $Z$. (ed.) Coral reefs. Elsevier, Amsterdam, p. 75-87

Norton, J. H., Jones, G. W. (1992). The giant clam. An anatomical and histological atlas. ACIAR Monograph. Australian Centre for International Agricultural Research, Canberra

Reid, R. G. B., Fankboner, P. V., Brand, D. G. (1984a). Studies on the physiology of the giant clam Tridacna gigas Linne. I. Feeding and digestion. Comp. Biochem. Physiol. 78A: 95-101

Reid, R. G. B., Fankboner, P. V., Brand, D. G. (1984b). Studies on the physiology of the giant clam Tridacna gigas Linne. II. Kidney function. Comp. Biochem. Physiol. 78A: $103-108$

Rosewater, J. (1965). The family Tridacnidae in the IndoPacific. Indo-Pac. Mollusca 1: 347-394

SAS (1985). SAS user's guide: statistics, Version 5 edn. SAS Institute, Inc., Cary, NC

Trench, R. K., Wethey, D. S., Porter, J W. (1981). Observations on the symbiosis with zooxanthellae among the Tridacnidae (Mollusca, Bivalvia). Biol. Bull. 161: 180-198 